\title{
Encapsulación de Probióticos de Secado por Spray
}

\author{
Spray-Drying Encapsulation of Probiotics
}

\section{Ofelia Alfaro-Galarza ${ }^{a^{*}}$, Norberto Chavarría-Hernández, Apolonio Vargas-Torres, Heidi M. Palma-Rodríguez}

\begin{abstract}
:
The probiotic microorganisms have gained importance in recent years because their consumption has benefits on health mainly of the digestive system. For this reason, the industry is in a constant search of processes for these micro-organisms don't lose their viability and they do their function. Because of that, the microencapsulation has been used as method of protection in the internal and external climate conditions. In this same vein, probiotics need prebiotic substances, such as malanga and rice starches, to stay viable and perform beneficial functions inside the host. The objective of this work was assess two prebiotics (malanga and rice starches) as wall material in the viabiity of a microorganism Lactobacillus casei subs. Paracasei encapsulated through spray dryed. The isolated malanga and rice starches, got 82.60 and $86.68 \%$ of starch overall respectively, in the amylose content rice presented $17.34 \%$ and malanga $9.44 \%$, the exponential phase of microoganisms was presented at $14 \mathrm{~h}$, aggregates with a popcorn shape were accomplished and finally the encapsulation effiency satyed in the order of 1008.
\end{abstract}

Keywords:

Probiotics, spray drying, encapsulation

\section{Resumen:}

En los últimos años los microorganismos probióticos han cobrado importancia, su consumo presenta beneficios en la salud, principalmente del sistema digestivo. Por esto, la industria se encuentra en constante búsqueda de procesos para que estos microorganismos no pierdan su viabilidad y cumplan su función, debido a lo cual se ha recurrido a la microencapsulación como método de protección frente a las condiciones ambientales internas y externas que puedan disminuir su viabilidad. En este mismo sentido, los probióticos necesitan de sustancias prebióticas, como lo son los almidones de arroz y malanga, para mantener su viabilidad y cumplir las funciones benéficas dentro del huésped. El objetivo de este trabajo fue evaluar dos prebióticos (almidón de arroz y malanga) como material pared en la viabilidad de un microorganismo Lactobacillus casei subs. Paracasei encapsulado mediante secado por aspersión. Los almidones de arroz y malanga aislados, obtuvieron 82.60 y $86.68 \%$ de almidón total respectivamente, en el contenido de amilosa arroz presentó $17.34 \%$ y malanga $9.44 \%$, la fase exponencial del microorganismo se presentó a las $15 \mathrm{~h}$, se lograron formar agregados con forma de palomita de maíz y finalmente la eficiencia de encapsulación quedo en el orden de $10^{8}$.

Palabras Clave:

Probioticos, secado por aspersion, encapsulado

\section{INTRODUCTION}

Currently there is a big problem in the food industry, in relation to the addition of probiotics in food, that is guarantee that such microorganisms arrive to the large intestine alive and in best conditions, no polluted and without variation or mutation, what it means; keep the functional cultivation, to carry this out is necessary to have a concentration of $1 \times 10^{7}$ UFC/mL at the moment of consumption Ding \& Shah (2007), among the different alternatives to avoid the lost and

Autor de Correspondencia, Universidad Autónoma del Estado de Hidalgo, Instituto de Ciencias Agropecuarias, Email: 
deterioration of probiotics, as well as their protection there is the encapsulation, the spray -drying is used to the conservation of acid lactic bacterial culture and is one of the methods that best results has provided to achieve this purpose Avila-Reyes et al (2014) consists in introducing the alive microorganisms in a matrix or wall material in the adequate quantities, so that their metabolic stability and functional activity be kept (Kun-Nan et al, 2005). On the other hand the prebiotics, help to stablish a suitable native flora that improve the immune defence functions of the host's intestine like others (Gibson \& Roberfroid, 1994), both native rice and malanga starch, are formed by small granules, in front of protein tend to form fiberboard microcapsules, so on their arrival to the colon are fermented by the existing microbiota. Are considered prebiotics because their resistance to digestion that can be caused by the limitations of physical accessibility, for the native starch granular structure or the pshysical modifications of the starches on the drying process, as a result, the objective of this work was to evaluate the prebiotics (rice and malanga starch) as wall material in the viability of microorganism Lactobacillus casei subs. Paracasei encapsulated by spray-drying.

\section{MATERIALS AND METHODS}

The rice starch was isolated in accordance with the reported methodology by Patindol et al., (2007) and malanga starch was gotten following the reported process by Flores-Gorosquera et al., (2004) For starch determination was used a test kit Megazyme for entire starch and amylose content was quantified following the Hoover and Ratnayake methodology (2001). The Lactobacillus casei subs paracasei exponential phase was established in accordance with Alvarez methodology et al. (2010). Previous to micro-encapsulation the microorganism reactivations were carried out, taking the aliquot to encapsulate in the exponential phase, in accordance with the mentioned before. The drying conditions used were: Intel tempreature: $70^{\circ} \mathrm{C}$, outlet temperatura: $42.5^{\circ} \mathrm{C}$ power flow of $10 \mathrm{~mL} / \mathrm{min}$. Subsequently were morphologically characterized the microcapsules through scanning electron microscopy following the Paredes-Lopez methodology et al., (1989), and it was determined the efficiency of encapsulation for both encapsulated.

\section{RESULTS AND DISCUSSION}

The total starch content for malanga simple (AM) was of $86.68 \%$ showing higher purify in comparison with rice starch (AA) (82.60\%). Subsequent to extraction process doesn't get $100 \%$ due to isolation efficiency as well as botanical sources where by obtained starch shows a remaining certain amont of lipids and proteins that were srawn with the process of isolating. On the other hand amylose content help us to classify the starch, the results showed that AA contained a $17.34 \%$ in accordance with the proposed clasification by Juliano (1992) for rice starch is waxy, if contains 0 $2 \%$ amylose, very low in amylose of $5-12 \%$, low in amylose $12-20 \%$, intermediate in amylose of $20-25 \%$ and high in amylose of $25-33 \%$, related to reported is low in amylose. For the AM was quantified an amylose content of $9.44 \%$, at being a tuber it may be classified as waxy starch, because it has been reported that contain less of $20 \%$ of amylose (Tester et al., 2004).

Lactobacillus casei subs. Paracasei growth kinetics (Fig. 1) was perfomed during 25 h, taking measure every 5 h. Related to the results gotten it was ovserved that exponential phase was at $15 \mathrm{~h}$ with an approximate population $2.43 \times 10^{09} \mathrm{UFC} / \mathrm{mL}$, this results are similar to the ones reported by Jurado-Gámez et al., (2014) who performed the Lactobacillus casei growth kinetics. getting the exponential phase at $16: 48 \mathrm{~h}$, with a population of $7.3 \times 10^{08} \mathrm{UFC} / \mathrm{mL}$.

In the microencapsulation the capsules formations depends on several facts among them the physicochemical properties of wall material, the micrographies gotten from the microcapsules next to the microorganism (Fig 2) through spray drying, with the different wall materials, were observed by scanning electron microscopy (SEM), to evaluate the shape, the surface appearance such as the integrity of the capsues and any damage evidency or ruptura. For the micrography made to AA is observed that granule starches suffer any change because of show "deflated", this could happen during the spray drying because the starch could have suffered any type of change which could be produced by 
the temperature, nevertheless Gonzalez-Soto et al., (2011) reported that gotten microcapsules for native rice starch through the spray drying have not an spheric shape, similar to the one obtained, for the case of malanga the spheric adding seems more regular little porosity and "popcorn" shape, this is because its low amylose content such as endogenous protein Zhao \& Whistler (1994), The obtained results for the viability of microorganisms show that both (rice and malanga starch) belongs to the same order of magnitude $\left(10^{8}\right)$, however malanga increase slightly the viability of Lacobacillus casei subs. Paracasei with a population $9.62 \times 10^{8} \mathrm{UFC} / \mathrm{g}$ in comparison with rice $\left(5.23 \times 10^{8} \mathrm{UFC} / \mathrm{g}\right)$, nevertheless it can be said that malanga starch forms better spherical aggregates for being of very small granule (2-3 $\mu \mathrm{m})$ which offer a higher protection to microorganisms in comparison from rice that is considered small $(2-10 \mu \mathrm{m})$ (Lindeboom et al., 2004).

\section{CONCLUTION}

Both rice and malanga starch offer an excellent option for the probiotic Lactobacillus casei subs. Paracasei, in as much as is carbon source is the glucose, however the viability of microorganism it looks less affected in the malanga starch because the microorganism are found inside the capsule and with less porosity among swarmed, contrary that occur with rice starch, that at the moment of having tow swarmed with small holes can make that microorganisms migrate to the exterior of micropause which will be exposed to the environment and affecting their viability.

\section{REFERENCES}

Ding, W. K., \& Shah, N. P. (2007). Acid, bile, and heat tolerance of free and microencapsulated probiotic bacteria. Journal Food Science, 72(9), M446-450.

Flores-Gorosquera, E., García-Suárez, F. J., Flores-Huicochea, F., Núñez-Santiago, M. C., Gonzalez-Soto, R. A., \& Bello-Pérez, L. A. (2004). Rendimiento del proceso de extracción de almidón a partir de frutos de plátano (Musa paradisiaca) estudio en planta piloto. Acta Científica Venezolana, 55, 86-90.

Gibson, R. G., \& Roberfroid, M. B. (1994). Dietary Modulation of the Human Colonic Microbiota: Introducing the Concept of Prebiotics. The Journal of Nutrition, 125, 1401-1412.

Gonzalez-Soto, R. A., de la Vega, B., García-Suarez, F. J., Agama-Acevedo, E., \& Bello-Pérez, L. A. (2011). Preparation of spherical aggregates of taro starch granules. LWT - Food Science and Technology, 44(10), 2064-2069.

Hoover, R., and T. Vasanthan. 1994. The effect of annealing on the physicochemical properties of wheat, oat, potato and lentil starches. Journal of Food Biochemistry, 17: 303-325.

Juliano, B. O. (1992). Structure, Chemistry, and Function of the Rice Grain and Its Fractions. Cereal Foods World, $37,772-779$.

Jurado-Gámez, H., Calpa-Yamá, F., \& Chaspuengal-Tulcán, A. (2014). Determinación de parámetros cinéticos de Lactobacillus casei en dos medios probióticos. Veterinaria y Zootecnia, 8(2), 15-35.

Kun-Nan, C., Ming-Ju, C., Je-Rui, L., Chin-Wen, L., \& Hsin-Ye, C. (2005). Optimization of Incorporated Prebiotics as Coating Materials for Probiotc Microencapsulation. Journal Food Science, 70, 260-266.

Lindeboom, N., Chang, P. R., \& Tyler, R. T. (2004). Analytical, Biochemical and Physicochemical Aspects of Starch Granule Size, with Emphasis on Small Granule Starches: A Review. Starch - Stärke, 56(34), 89-99.

Paredes-López, O., Schevenin, M. L., Hernández-López, D., \& Cárabez-Trejo, A. (1989). Amaranth Starch-Isolation and Partial Characterization. Starch Stärke, 41, 205-207.

Patindol, J. A., Gonzalez, B. C., Wang, Y.-J., \& McClung, A. M. (2007). Starch fine structure and physicochemical properties of specialty rice for canning. Journal of Cereal Science, 45(2), 209-218

Tester, R. F., Karkalas, J., \& Qi, X. (2004). Starch-composition, fine structure and architecture. Journal of Cereal Science, 39(2), 151-165.Zhao, J., \& Whistler, R.L. (1994). Spherical aggregates of starch granules as flavor carriers. Food Technology, 48, 104-105 